\title{
Security of construction sites: risk-management
}

\author{
Sergei Deordiev*, Victor Kudrin, Mariya Plyasunova \\ Siberian Federal University, School of Engineering and Construction, 660041, Pr. Svobodny 82, Russia
}

\begin{abstract}
This article has certain goals and tasks for solving some engineering problems. The analysis of the situation regarding the applicability of risk management in the construction industry of the Russian Federation is presented. The reasons for the low prevalence of this means of ensuring the mechanical safety of buildings and structures are revealed. Examples of the application of risk management in the West, as well as examples and reasons for non-use in Russia are given. Measures and recommendations are proposed to change this situation in the construction sector. References are given to sources with weighty arguments for the application of building safety.
\end{abstract}

\section{Introduction}

The necessity and urgency of improving the efficiency of the means of provision of mechanical safety of buildings and structures (PMSBS) based on the Federal law technical regulations TR* [2] is undisputed [4, 5].

Such measures include the use of methods and tools of risk management (the process of making and implementing management decisions aimed at reducing the probability of an adverse result and minimizing possible losses caused by its implementation) [6].

Risk management (RM), which initially came into being as the regulation of insurance relations in the process of protection against unpredictable events, leading only to damage and beyond the reasonable control of entrepreneurs, is an indispensable attribute of the western security model [6-8].

The goal and objectives of this work is to evaluate the cause of the low prevalence of this element of the PMSBS system in the construction industry of the Russian Federation, to propose measures to change the current situation.

Among the reasons for the low prevalence of international experience of the RM in Russia [9-11] are the following factors: significant differences in the organizational structures of the enterprises and characteristics of the economy, relatively high and long-term costs of development of risk management systems that have a large payback period; lack of stable and developed market of financial instruments, trained personnel and the overall low level of insurance culture.

Only large Russian enterprises have now decided to apply the RM under the pressure of foreign investors or partners. In addition, their PM is often declarative in nature - they do not create a comprehensive risk management system that would cover the entire range of risks, but are limited to either decentralized monitoring of local risks or the use of insurance protection $[8,9]$.

However, according to some authors [12], modern (Anglo-Saxon) detached from real insurance RM protects business from risks very badly. Risk management of the company has become a subject of interest and influence of structures, government bodies and even individual citizens external to it.

The reasons for the RM non-use in construction are also affected by the specificity of the industry and a speculative economic model of construction, for which it is advantageous to build expensive and poor quality housing and not much [13].

For the builders of standard housing, technological risks are so banal that some special attention is not required. All the risks associated with external infrastructure are more important for them. Therefore, RM is often replaced by diversification of activities. If there is an opportunity to create your own, or absorb an adjacent infrastructure unit, they prefer to work with their own designers, suppliers, transporters and even have a private security company that ensures the inviolability of the territory [14].

This approach has a significant drawback. Investment in construction-related businesses does not allow to expand the construction business itself. In addition to limiting the volume of investment, development in this case rests on the need to keep under control not only the risks of the construction business, but also growing as snowball risks of newly created related companies. Neither insurance nor traditional RM will help to cope with this disaster.

With the builders of large unique objects, the RM is usually implemented «in a Soviet style», as a rule. And this is not surprising, because when there are no commercial risks and the state is the only customer and controller, the illusion of the great construction of socialism is created.

\footnotetext{
* Corresponding author: deordievsv@ yandex.ru
} 
In such circumstances, specialists working on the project are forced to provide a full range of measures to prevent the risk of the object and adjacent areas destruction. In the process of construction itself, the risks are minimized by compliance with technology and basic safety. The reserve of unforeseen events, traditionally laid in the estimates, the years of experience gained since the Soviet times have added to the builders' confidence.

All would be good if not for one thing: it is impossible to completely eliminate the possibility of large risks in the construction of unique objects, and if trouble happens, the state will not be in a hurry to cover the damage from the budget. As for the responsibility, up to criminal, for causing damage to the customer and to the affected third parties, it is borne by the contractor who will have to answer in full.

Therefore, a preventive measure is called for - to insure all construction risks. But there are a lot of risks, and not a single insurance company will take full responsibility without understanding the details.

Apart from that, the construction budget allocates only a certain amount of money for insurance. This is where the problem of risk management begins, because the established figure leaves much to be desired.

The insurer in such a situation is driven into very rigid limits - he is to identify the most relevant risks, which can result in really possible large losses, and to insure them. In some cases, it is insurance of property risks or expensive equipment, or the third parties responsibility. The determination of limits on the types of risks and franchise sizes, the allocation of the most probable risks, as well as the cut - off of those types of insurance, the costs of which can be replaced by other, cheaper preventive measures-all this in the Russian practice falls on the shoulders of the insurer. However, only a few Russian companies have the necessary experience.

For these reasons, the builders are not insured at all from all risks, with the exception of companies working with foreigners or for foreigners (for them it is not only a way to protect themselves from possible risks, but a matter of prestige, as well as a kind of guarantee to attract new investments).

According to [15-17], in addition to insurance against accidents at work, two more systems are developing in the construction sector: insurance carried out within the framework of membership in self-regulatory organizations (SRO), and voluntary insurance of construction and installation risks (CIR).

The insurance provided within the framework of the SRO membership from a formal point of view is also voluntary, although all self-regulatory organizations oblige their members to enter into insurance contracts.

Since the recovery, after the payment of the insurance amount, will be drawn to the company's own funds, the insurance amount is reduced to the minimum required only to obtain a certificate of admission to work in the SRO that affects the safety of capital construction projects.

In case of causing harm in a large amount, it is more profitable for the construction participants to liquidate the organization and create a new one than to conclude an insurance contract for a commensurate insurance amount. The methods of «liquidation» of organizations have long been known to all entrepreneurs.

The contract of the CIR insurance in its legal nature is mixed, including usually insurance of property of the insured, safety of the construction equipment and civil liability of the construction organizations for the harm caused to the third parties (CL).

In some cases such a contract includes insurance of business risk in terms of non-receipt of expected income. Sometimes it is envisaged to insure the so-called associated risks, such as construction materials in warehouses serving a specific construction site, vehicles and other special equipment (cranes, bulldozers, etc.), civil liability that may arise when they are used.

Since the CIR contract, as a rule, does not prescribe the proedure of strict correlation of this requirement with the schedule of the operation financing, as in standard contracts abroad, the contractors strongly shy away from such insurance even when the contract contains a requirement for insurance.

In addition, the profits of most insurance contractors allow them to enter into contracts with only small amounts of insurance that cannot cover all possible damages. This leads to a natural desire to minimize insurance costs in order to increase today's profits by concluding contracts with any insurance company that has established a lower rate without taking into account its reputation and guarantees.

The CIR insurance in Russia, unlike the other countries, is not mandatory. This is determined by the provisions of parts 2 of Article 927 and 4 of Article 935 of the Civil Code of the Russian Federation (CCRF).

Insurance activity, including the field of construction, is regulated by the Federal law of the Russian Federation dated 27.11.1992 No. 4015-1[19].

There are also «Methodological materials on insurance of construction risks « [20], recommended by the letter of the Ministry of Construction of the Russian Federation dated 30.08.1996

Although these materials are not mandatory, they are used in the assessment of damage from construction works. Many builders are not insured at all. The approach is simple - «if there is an insurance event - we will pay, or - save on insurance.»

In this respect the insurance is also influenced by the quality of provided insurance services and the size of the reimbursement, from the standpoint of compensation in the event of an accident at the facility.

Formally, according to the provisions of parts 2 of Article 9 and 3 of Article 10 of the Federal Law № 4015-1 and paragraph 8.1.2 1 of Methodical Materials on Building Risk Insurance (MMBRI), policyholders have the right to receive insurance compensation in the amount of direct actual damage within the insurance amount, taking into account the specific conditions specified in the insurance contract.

However, in practice in addition to timely notification of the occurrence of an insured event, they still have to prove that the latter does not apply to the exceptions, and they informed the insurer in time about the change in the material 
circumstances that took place during the period of the insurance contract, as well as fulfilled or at least did not violate the requirements of paragraphs 8.2 and 8.3 of the MMBRI.

Taking into account the reluctance of the insurer to pay the bills at all (because insurance is a business, and this is its direct losses), the task for the policyholder to prove his case is not easy. Often, everything is solved only in the courts.

It should also be noted that when insuring objects under construction, in addition to the standard exceptions set out in article 964 of the Civil Code, losses caused by errors of designers, the use of poor-quality building materials and structures caused by rain, hail, snow, penetrated into open windows or other openings are not covered, if they are not formed as a result of a storm; damages to property due to its decay, due to long-term operation and a number of other circumstances are not covered as well.

In addition to these tricks, the management of the insurance company itself may be weak, and its employees are not professional enough.

The insurers also manipulate with the size of the franchise - the non-refundable part of the loss. Some of them greatly overestimate this amount, due to which many accidents at the construction site do not exceed the franchise and will not be paid for.

Tariff rates of insurers are far from perfect. In contrast to insurance of hazardous production facilities, where the Bank of Russia's instruction No. 4234 of 19 December 2016 clearly defines the amount and structure of tariff rates, each of the insurers can dictate his own rules with respect to other objects of insurance to the extent of their competence and greed.

There is also a significant dependence of the quality of insurance services on the effectiveness of the interaction of insurers with reinsurance companies. Prices in the reinsurance market are quite high. And reinsurers-world known leaders provide their services not for all Russian companies. This requires long-term partnerships and an impeccable reputation of the insurer.

The payout ratio (the percentage of all reimbursements paid to all insurance signed premiums) according to [17], for our insurance companies is not more than $48 \%$ (for European companies it is $80 \div 90 \%$ ).

According to [21], the market of the CIR insurance in Russia at the end of 2015 was represented only by $20 \div 30$ companies. In 2014 they were able to earn 40 billion rubles on the CIR policies, which is only $3 \div 4 \%$ of the entire insurance market of the Russian Federation.

Until 2015, 70-80\% of the total premium on the CIR insurance insurers received under contracts that were concluded in construction on the budget means (in 2015 the Ministry of Construction issued an order, which obliged not to pay the CIR costs in the estimates of state construction).

It is quite difficult for the supervisory authorities to control the CIR insurance markets, because even working with a certified construction company, it is necessary to take into account a lot of contractors and subcontractors.

\section{Conclusions of the analysis}

1. The complex Anglo-Saxon model of integrated risk management for several reasons has not found wide application in Russia. Domestic RM is limited, and this is reasonable, either by decentralized monitoring of local risks or by the use of insurance protection.

2. The current insurance does not cover the real losses of the policyholder. Russian builders, except for «mandatory» insurance against accidents at work are voluntarily insured only against installation risks, carried out within the framework of the SRO membership.

3. The builders can choose not to be insured at all: business understands that it is impossible to recover from it, so it does not see the need to insure risks.

4. The reasons for this attitude of builders to insurance are due to their mentality, economic reasons, underdevelopment of the insurance market (weak legal framework for the functioning of companies that insure the risks of major damages, lack of professionalism of their employees), greed and dishonesty of insurers.

5. To reduce the burden on the budgets of all levels due to the payment of compensation for losses as a result of accidents or natural disasters, which is still observed in practice, it is necessary to build confidence in both the insurance institutions and the insurers themselves.

\section{References}

1. S.V. Klyuev, A.V. Klyuev, A.D. Abakarov, E.S. Shorstova, N.G. Gafarova, Mag. Civ. Eng. 75,

2. $\quad$ 66-75 (2017) doi:10.18720/MCE.75.6

3. On technical regulation: federal law of 27.12.2002 no. 184-FL (edition of 29.07.2017) URL:http://www.consultant.ru/document/cons_doc_LAW_40241 (Accessed 24 september 2018)

4. D.A. Vakulenko, R.A. Turusov, Mag. Civ. Eng. 75, 106-113 (2017), doi:10.18720/MCE.75.10

5. R.A. Ibragimov, S.I. Pimenov, V.S. Izotov, Mag. Civ. Eng. 54, 63-69 (2015), doi:10.5862/MCE.54.7

6. Endzhievskij L.V., Kudrin V.G., Sebeshev V.G. Otsenka otechestvennoj normativnoj bazy obespechenija mehanicheskoj bezopasnosti sooruzhenij [Assessment of the domestic regulatory base to ensure mechanical safety of structures]. Izv. vuzov. Ser. Stroitel'stvo, 4 (2017) 
7. 6. Akrapovich R. Energoeffectivnost: problems and perspectives of growth // Infomational paper. Tehexpert. 2017, 4, 7-10

8. A.V. Denisov, Mag. Civ. Eng. 73, 70-87 (2017), doi:10.18720/MCE.73.7

9. R.A. Ibragimov, S.I. Pimenov, Mag. Civ. Eng. 62, 3-12 (2016), doi:10.5862/MCE.62.1

10. A.R. Gaifullin, R.Z. Rakhimov, N.R. Rakhimova, Mag. Civ. Eng. 59, 66-73 (2015)

11. Lajkov A.Ju. Upravlenie riskami: genezis ne effektivnosti, «best practices» dlja patsientov i vozvraschenie k istokam [Risk management: the genesis of inefficiency, «best practices «for patients and return to basics].Strahovoj internetportal Rossii «Strahovanie segodnja».URL: http://www.insur-info.ru/analysis/991/ (data obraschenija: 24.01.2018)

12. Baboshin M. Stroitel'stvo v voprosah i otvetah [Construction in questions and answers]. Informatsionnyj bjulleten' Teh 'ekspert, 5 (2014)

13. Shuvalova I. Chto im stoit dom postroit': o praktike risk-menedzhmenta $\mathrm{v}$ stroitel'stve [No problem in housing construction: on the practice of risk management in construction]. Portal 'Ekspert, 42 (348) 11 nojabrja 2002 g. URL: http://www.insur-info.ru/press/50344/ (data obraschenija: 24.01.2018)

14. M. Gravit, O. Nedryshkin, A. Zhuravlev, Negative use of finishing materials on Sorel's cement. In MATEC Web of Conferences; Vol. 106

15. V. Susoeva, T.N. Vahnina, A.A. Titunin, J.A. Asatkina, Mag. Civ. Eng. 71, 39-50 (2017), doi:10.18720/MCE.71.5

16. Osobennosti strahovanija stroitel'no-montazhnyh rabot (SMR) po polisam CAR i EAR [Features of insurance of construction and installation operations (CIO) with CAR and EAR policies]. Internet-zhurnal strahovkunado.ru.URL: http://strahovkunado.ru/insur/strakhovanie-cmr.html (data obraschenija: 24.01.2018)

17. S. Shepelenko, N.P. Gorlenko, O.A. Zubkova, Mag. Civ. Eng. 81, 125-134 (2018), doi:10.18720/MCE.81.13

18. S.Y. Shekhovtsova, A.V. Korotkov, M.A. Vysotskaya, Mag. Civ. Eng. 78, 91-100 (2018), doi:10.18720/MCE.78.7

19. L.V. Zakrevskaya, P.A. Lubin, S.N. Avdeev, I.A. Gandelsman, S.V. Filippov, Mag. Civ. Eng. 75, 123-128 (2017), doi:10.18720/MCE.75.12

20. L.V. Zakrevskaya, A.A. Gavrilenko, S.N. Avdeev, I.A. Gandelsman, A.V. Kireev, Mag. Civ. Eng. 77, 121-129 (2018), doi:10.18720/MCE.77.11

21. Stenogramma diskussii na temu: «Strahovanie stroitel'no-montazhnyh riskov v Rossii»[Transcript of the discussion: «Insurance of construction and installation risks in Russia]. Rejtingovoe agentstvo RAEX («'Ekspert RA»). URL: $\mathrm{http} / / /$ www.raexpert.ru/project/gm_risk/2011/stenogramma/(data obraschenija: 24.01.2018)

22. T.V. Bobrova, P.M. Panchenko, Mag. Civ. Eng. 76, 84-97 (2017), doi:10.18720/MCE.76.8

23. V.V. Sharmanov, T.L. Simankina, A.E. Mamaev, Mag. Civ. Eng. 69, 77-88 (2017), doi:10.18720/MCE.69.7

24. Bril, A., Kalinina, O., Zotova, E., Vilken, V. Increasing the efficiency of personnel management in municipal organizations through controlling operational risks and fixed costs (2018): MATEC Web Conf 